\title{
The First Two Decisions of the Australian Fair Pay Commission: A Critique
}

\author{
Philip Lewis ${ }^{1}$
}

\begin{abstract}
The Australian Fair Pay Commission (AFPC) was established by the Howard government under the controversial WorkChoices legislation. It was heralded by its supporters as a major improvement on the previous system of safety-net wage cases under the Industrial Relations Commission and universally condemned by the union movement and Labor. Others questioned whether a minimum wage was needed at all or even whether it was a major impediment to labour-market adjustment. The AFPC's first and subsequent decisions were, therefore, looked on with interest by the media, academics, politicians and vested interests. This paper provides a critique of the AFPC's first decisions and suggests how the process of arriving at a minimum wage could be improved.
\end{abstract}

\section{Background}

Australia had, until fairly recently, a system of wage determination, and of industrial relations more generally, that had only one or two counterparts in the rest of the industrialised world. Although this system underwent considerable change under the Hawke/Keating governments and this continued under the Coalition administration, a major distinguishing feature of the Australian system remained the role played by a range of arbitration and conciliation tribunals, the dominant institution being the Australian Industrial Relations Commission (AIRC), although it formerly had other titles. These tribunals set the minimum rates of pay and the conditions of work of employees set out in awards. However, by 2005 only about 20 per cent of Australian workers relied on awards for their pay determination. National awards took as their benchmark the so-called safety-net increases determined by the National Wage Case decisions of the AIRC. These decisions were made after an exhaustive process of written submissions by employer groups, unions, government bodies and other interest groups, with evidence and cross-examination taking place in an adversarial court-like setting lasting several months.

With the passing of the WorkChoices legislation in 2006 the role of the AIRC in setting minimum wages, and the subsequent changes to national awards, passed to the newly created Australian Fair Pay Commission (AFPC). The five

${ }^{1}$ Centre for Labour Market Research, University of Canberra, phil.lewis@canberra.edu.au 
commissioners, including the chair, Professor Ian Harper, were appointed by the government and differed from the AIRC Commissioners, many of whom had had extensive experience in the court room of the AIRC in their role as union or employer advocates. AFPC decisions were to be made on the basis of legislation alone, not based on arbitration between multiple parties, through a review process rather than a court-like process. Perhaps most importantly the AFPC had to consider in its reviews the capacity of the unemployed and low paid to obtain and remain in employment, something which could not be considered by the AIRC.

The AFPC was heralded by its supporters as a major improvement on the previous system of Safety Net wage cases under the AIRC, but it was universally condemned by the union movement and Labor; and some economists questioned whether a minimum wage was needed at all or even whether it was a major impediment to labour-market adjustment.

In its first decision in October 2006, the AFPC handed down a two-tiered increase, with an immediate adjustment to the minimum wage of $\$ 27.36$ and a lesser increase for awards above $\$ 700$ per week. And while it did cover a period of 18 months since the previous Safety Net adjustment by the AIRC, and therefore on an annual basis could be seen as equivalent to an increase of $\$ 18.24$ (or 3.8 per cent) for each year, employers were taken by surprise in regard to the size of the increase granted. In its second decision, in July 2007, the AFPC increased the standard Federal Minimum Wage and all pay scales up to $\$ 700$ a week by $\$ 10.26$ per week and all pay scales paying $\$ 700$ and above a week by $\$ 5.32$ per week. Both increases applied from the first pay date on or after 1 October 2007. Taken together, the AFPC's 2006 and 2007 increases delivered an additional $\$ 37.62$ per week to Australia's lowest-paid workers.

What was of note was that the two increases over the respective period since the previous Safety Net adjustments were, in percentage terms, almost identical to the movement in the Consumer Price Index (CPI) over the same period (the increase in the minimum wage between April 2003 and October 2007 was 7.8 per cent compared to a rise in the CPI between March 2003 and September of 7.3 per cent). It therefore had for employers an ominous look of having been an increase based on the underlying, but un-stated, concept of wage indexation.

The concern therefore was that a process of wage adjustment was being introduced which, for all the gloss of it being economically based, was in reality a continuation of centralised wage fixation (AIRC 2005) under a different name. No principles were being introduced that would provide an upper limit on the level of increase. Indeed, as discussed below, the AFPC, in its interpretation of the legislation, introduced virtually no principles at all, and the appearance of a system of an ad hoc decision-making process based on the personal views of the five commissioners was the essence of the new system. 
Of even greater concern was the absence of any evidence that the AFPC considered the capacity of the unemployed and low-paid to obtain and remain in employment, despite the legislative requirement that it do so. Given this neglect, the paper now turns to unemployment, and the impact of minimum wages on employment. The sections that follow argue the need for greater consideration of the jobless in minimum-wage decisions, the need for a better framework in reaching these decisions and, finally, some thoughts on how the new federal government might improve on the current arrangements.

\section{Is there an unemployment problem?}

Figure 1 shows the history of the unemployment rate in Australia since the 1960s. Clearly, the historical average until the mid 1970s was about 2 per cent but rose almost continuously until the early 1980s.

Figure 1: Unemployment Rate (\%), 1960-2007

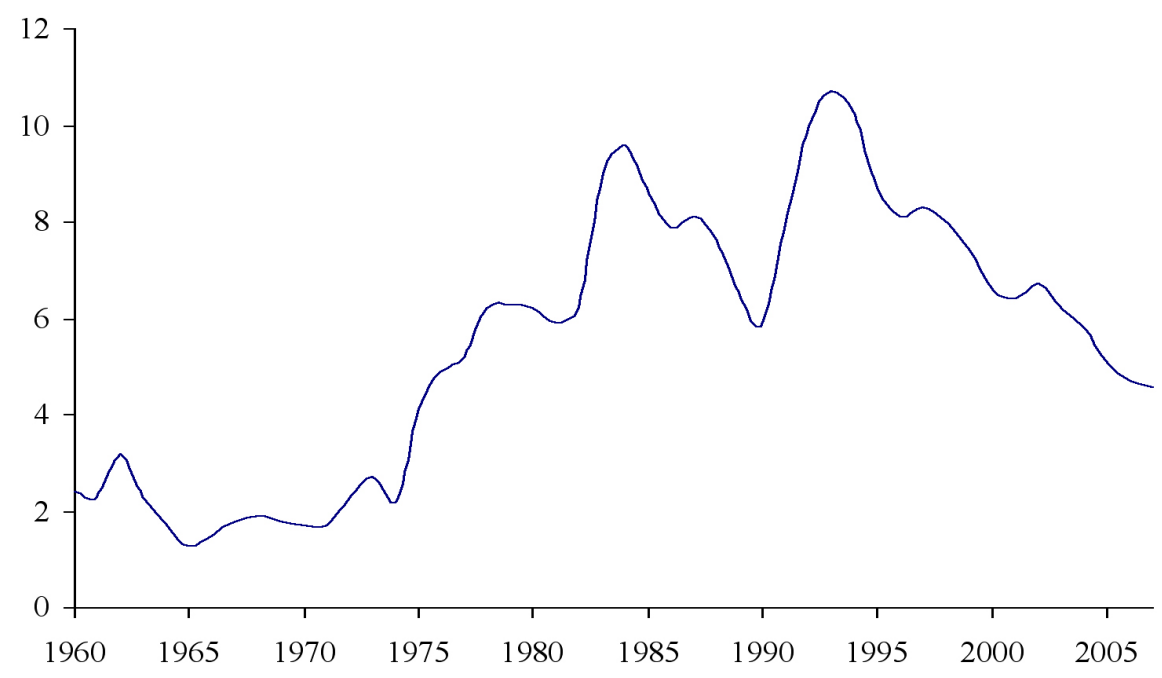

Source: Australian Bureau of Statistics, Labour Force, cat no 6203.0, 6202.0

Since the early 1990s over 15 years of extraordinary economic growth (by OECD standards) have been accompanied by a decline in the unemployment rate to about 4.3 per cent in June 2007 (when the AFPC was considering its second decision) or 472000 people. $^{2}$

At a time when the unemployment rate is the lowest for over 30 years it would be tempting to conclude that joblessness is no longer a problem in

\footnotetext{
2 It may be observed that while macroeconomic policy can cause significant increases in unemployment, as witnessed by 'the recession we had to have' in the late 1980s, it is evident from a lengthy spell of remarkable economic growth that unemployment is not going to be solved by macroeconomic policy alone, nor should it be expected to.
} 
Australia. However, as I hope to demonstrate by examining a broader range of statistics than simply the unemployment rate, this is far from the case.

The shortcomings of the unemployment rate as an estimate of excess supply of labour are well known to labour economists but not widely understood by the community as a whole or even among those regarded as informed commentators. For instance, in the ABS Labour Force Survey, from which the unemployment estimates are derived, it is only necessary to have worked for one hour in the survey week to be classified as employed. In order to be classified as unemployed, respondents must pass a number of tests regarding their readiness for work and their efforts to actively seek work.

There are a number of other measures which shed light on the extent of under-utilisation of labour. One of these is the underemployed, those who are either part-time workers who want (and are available for) more hours of work than they currently have; or full-time workers who worked part-time hours during the reference week for economic reasons. In September 2006, when the AFPC was considering its first decision, the number of underemployed was put at 544600 , raising the labour force under-utilisation rate to 9.8 per cent compared to an unemployment rate of 4.8 per cent (ABS 2006).

Another measure is the marginally attached, who want work but do not satisfy the strict availability criteria. They are those who were actively looking for work, but not available at the time of the survey or were available to start work but did not believe they could find a job. Another definition of marginal attachment used by the ABS relates to those who are looking for work, available for work or would look for work if they could. In September 2006, the number of such people stood at 274000 .

While the unemployment rate has fallen significantly over the 1990s and 2000s, the underemployment rate actually rose (from 5 per cent in 1993 to over 6 per cent in 2006), while there has been little change in the marginally attached. Adding the underemployed and the marginally attached more than doubles the official number of unemployed to about 1.3 million.

The number of those on social security payments is another possible indicator of unemployment. The ABS bases its estimates of the unemployed according to individual responses to survey questions. However, eligibility for social security payments is determined by an individual's awareness of, and the ability to convince Centrelink of, eligibility for benefits. Figure 2 shows how the number receiving certain categories of benefit (namely, sole-parent, disability and unemployment benefit) changed over time. There are some interesting features of these data in respect of the number of recipients at any given time and with respect to trends over time. 
Figure 2: Social Security Recipients, 1980-2005 ('000s)

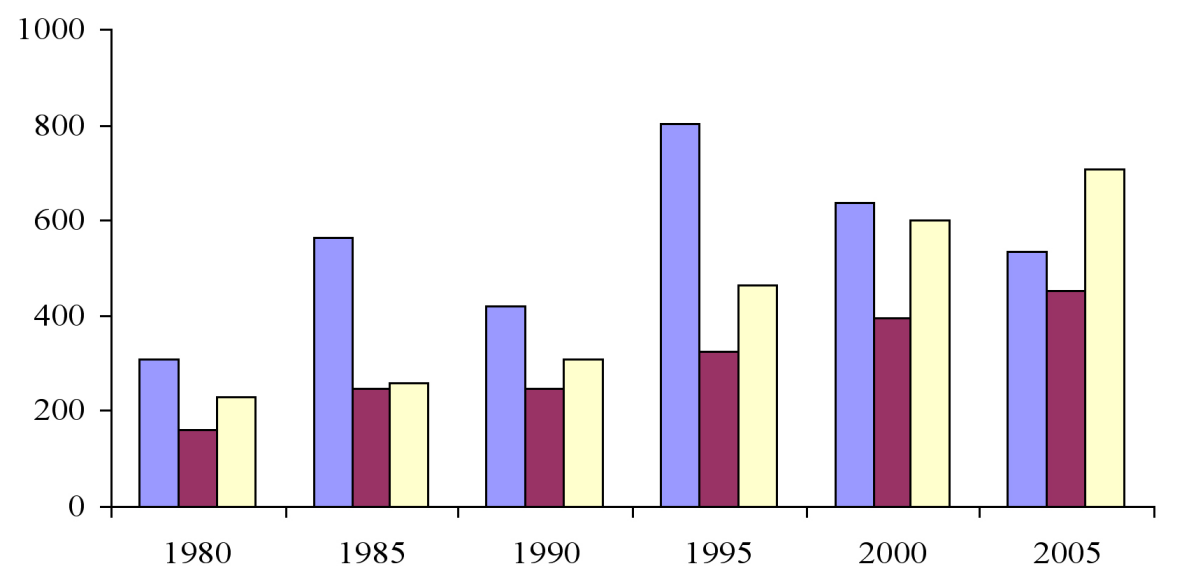

$\square$ Unemployed $\square$ Single-Parent $\square$ Disability Support

Note: The Unemployed in the above figure are those on unemployment benefit, not those classified as unemployed in the Labour Force survey.

Source: Winter (2000) Social Security Recipients, 1970-2000, http://www.aph.gov.au/LIBRARY/pubs/rn/2000-01/01RN15.htm, and Australian Bureau of Statistics, Australian Social Trends, Cat No. 4102.0.

The number of people on unemployment benefit tracks roughly the ABS unemployment estimates shown in Figure 1. However, in every year the number of people receiving unemployment benefits exceeded the number unemployed. The number of people receiving single-parent pensions more than doubled over the 20 years up to 2000, and continued to rise by 2005. Perhaps most interesting is the rise in people on disability pensions in inverse relation to those on unemployment benefit. There appears to have been a movement from unemployment benefits to pensions which, while reducing the figures for those on unemployment benefits, is costly for government since pensions are indexed to male total average weekly earnings while unemployment benefits are indexed to the Consumer Price Index.

In summary the extent of the unemployment problem is somewhere between 500000 (the Labour Force Survey) and 1.7 million people (those on benefits).

Further, significant changes have occurred in the composition of employment since the 1980s. Perhaps the most significant impact has been on employment of males. Table 1 shows the annualised rate (not compounded) of growth in employment between 1981 and 2007. 
Table 1: Employment Growth, annualised percentage change, 1981-2007

\begin{tabular}{lll}
\hline & Full-time & Part-time \\
\hline Full-time Males & 1.0 & 12.5 \\
Full-time Females & 2.7 & 6.8 \\
Full-time Persons & 1.5 & 8.0 \\
\hline
\end{tabular}

Source: Labour Force, ABS Cat. No. 6203.0, 6202.0

The major trend in the Australian labour market is that the demand for full-time workers, particularly males, has not kept pace with supply. There has been a substitution of females, particularly part-time females, for full-time males. For particular groups, the changes in demand have been particularly noticeable. For instance, a full-time job for anyone 15-20 years old is now an exception rather than the rule and employment prospects are poor for many displaced older males (Lewis 2002).

\section{The economics of unemployment and the minimum wage}

The starting point here is the standard neoclassical analysis. The clue to understanding the minimum wage debate is the nature of the labour market in determining the overall level of employment and unemployment. The standard textbook treatment shows that if average wages are held at a minimum above the equilibrium wage then labour supply exceeds labour demand, resulting in unemployment. There is considerable empirical research on the labour market in Australia and the effect of rises in average wages on employment (see, for instance, Lewis and Seltzer 1996; Bernie and Downes 1999; Lewis and MacDonald 2002). This research indicates that a 10 per cent increase in average wages reduces employment by about 8 per cent. Thus, moderation in average wages increases employment and, with the usual caveat that all other things are equal, unemployment will fall.

One of the major factors in the fall in the unemployment rate since the mid 1980s is the fall in real unit labour costs (RULC) over the same period. RULC is the cost of employing labour adjusted for inflation and labour productivity, expressed as an index. RULC can fall due to wages rising slower than inflation or rising by less than the growth in productivity. The Australian Bureau of Statistics (ABS) has recently begun publishing historical estimates of RULC for the Australian economy and these are shown Figure 3. It is generally recognised by economists that the demand for labour (employment) is strongly inversely related to RULC (Lewis and MacDonald 2002). 
Figure 3: Real Unit Labour Costs, 1984-2006

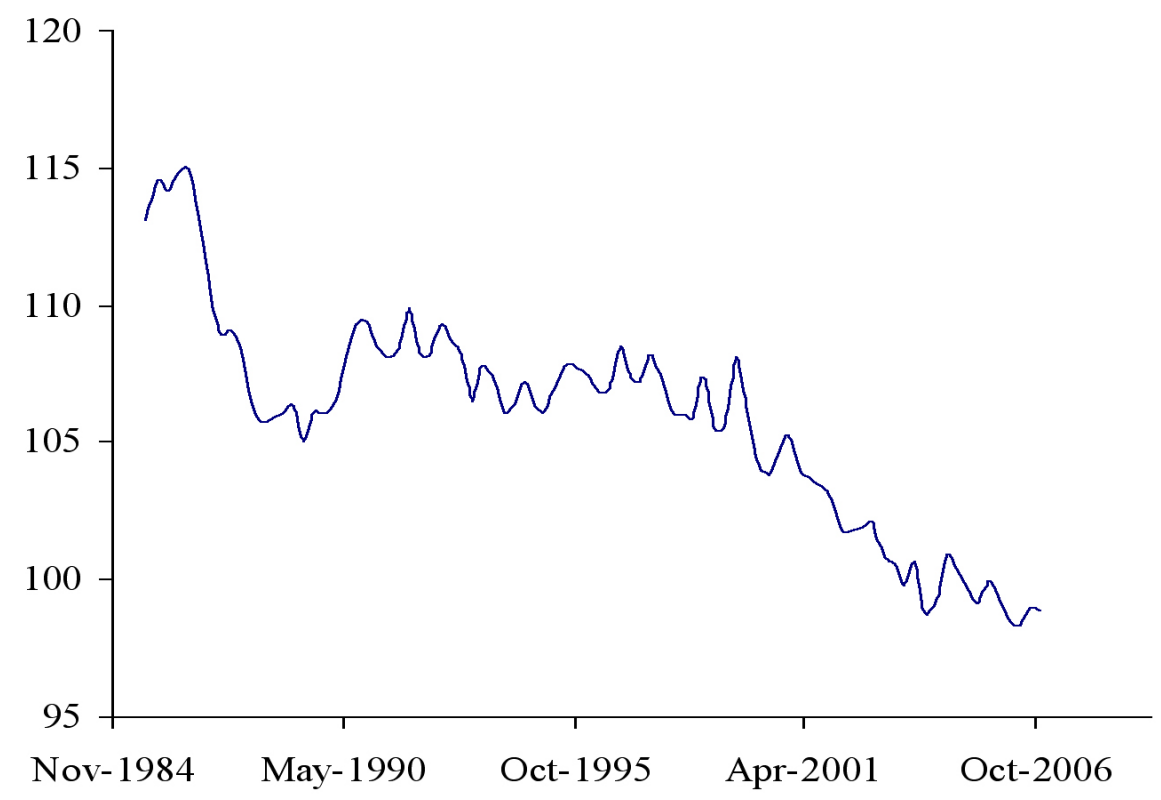

Source: Australia's National Accounts, ABS cat no 5206.0, Table 38

The very high level of RULC in the early 1980s is clearly evident and was associated with the very high levels of unemployment (see Figure 1) at that time. The success of the Prices and Incomes Accord in breaking the nexus between wages and prices, particularly through the ending of full indexation, was particularly important in reducing RULC and unemployment (Lewis and Spiers 1990). The continuing fall in RULC through the 1990s and 2000s was due to microeconomic reform, including labour-market deregulation by successive ALP and Coalition governments.

It is tempting to use the above analysis to argue the effects of imposing a minimum wage for the lower paid. However, the above analysis needs to be adjusted for the analysis of minimum wages. Since most workers would obtain a wage higher than the minimum anyway, the effect of imposing a minimum wage is to increase the wages only of those who would otherwise receive the lowest wages. The effect on the average wage is small and, thus, the impact on total employment and unemployment is also small. The international empirical evidence confirms that the impacts of minimum wages on total employment and unemployment are small (Brown, Gilroy and Kronen 1982; Neumark et al. 2000). In the only recent study for Australia, Leigh $(2003 ; 2004)$ also presents evidence which indicates a small but significant effect. However, despite small effects on total employment, the impact on the low-skilled is high. 
To get to grips with the effects of a minimum wage it is necessary to dig deeper into the operations of the labour market. The impact of the minimum wage on employment depends on four effects - the substitution effect, the truncation effect, the leakage effect and the output effect.

An important characteristic of the multitude of labour markets is substitutability. In reality there is not a single labour market but, rather, very many labour markets, each with its own supply and demand. Although it is common, particularly in the professions, to think of occupations being rigidly defined, in practice there is a great deal of substitutability between workers (Lewis 1997). There is also strong evidence that, given the degree of substitutability, the demand for labour in these more narrowly defined labour markets is highly responsive to relative wages (Hamermesh 1993; Lewis 1985; Daly et al. 1999). ${ }^{3}$

The imposition of minimum wages only directly affects those in or seeking low-skilled, low-paid jobs. These individuals are, generally, very poor substitutes for the majority of the workforce and, therefore, minimum wages have little impact on the wages and employment of most workers. However, those workers who have a market wage just above the minimum wage are highly substitutable for minimum wage workers.

Firms employ fewer of those who would have earned below the minimum wage and, therefore, unemployment among this group rises. However, these workers are substituted by more workers earning just above the minimum wage. The net effect on total employment may be difficult to detect.

In summary, the impact of the minimum wage on total employment may be proportionately small but the impact on low-skilled, low-paid workers is disproportionately high. There is a large fall in employment of workers who could otherwise have earned below the minimum wage. Minimum wages are all about distribution. Jobs and income are redistributed away from the worst off.

The truncation effect relates to the extent to which the imposition of the minimum cuts into the distribution of jobs. The larger the minimum wage relative to what the market wage would otherwise be, the larger the truncation effect (the loss of jobs). In Australia the minimum wage is high relative to average weekly earnings by international standards (Lewis 2006). The estimates of excess supply earlier in the paper, between 500000 and 1.7 million, suggest that the truncation effect is high. Of course, because Australia has long had a minimum wage we cannot tell what the market wage would be if there were no minimum. However, it can be deduced from the characteristics of the unemployed,

3 In addition to labour-labour substitution, there is also likely to be a high degree of capital-labour substitution since capital and low-skilled labour are generally highly substitutable (Hamermesh 1993). 
particularly the long-term unemployed, namely that they are low skilled, that their market wage would be low (Argy 2005).

In summary, the characteristics of the unemployed plus the magnitude of the number of jobless suggests that the substitution and truncation effects are very high. Therefore, the minimum wage is clearly well above the wage which would equate demand and supply.

With regard to the leakage effect, there is little evidence except casual empiricism that 'cash out of the till' payments may be common for many employers of unskilled workers in some industries. The high preponderance of students and overseas backpackers in these industries may also be some indication of the willingness of people to supply labour in these jobs.

Finally, the output effect depends on how large labour costs are as a proportion of total costs and how sensitive is consumer demand to increases in prices resulting from wage rises. Minimum-wage jobs are generally in labour-intensive industries with high responsiveness to prices and therefore we would expect that the output effect is relatively large.

\section{Monopsony, anyone?}

It is worth digressing somewhat here. In recent years there has been a concerted campaign to challenge the economic orthodoxy and suggest that labour markets are somehow different to other markets. Essentially, proponents of this view try to argue it is possible for wages and labour demand to both rise! The foundation for these ideas is the work of Card and Krueger (1995). Robson (2004) has provided a lively and convincing criticism of this view and the critique below borrows heavily on his reasoned arguments (see also, ACCI 2006; Moore 2002). The empirical findings of Card and Krueger for the United States have also been heavily criticised (see, for example, Ehrenberg 1995; Osterman 1995; Seltzer 1997).

The basis of the argument is that the labour market is characterised by monopsony, whereby some employers have monopoly power in the hiring of workers. Monopsony power is where an individual employer is able to exert control over the level of wages due to their market power. This situation can arise where there is a single employer of a certain type of labour, or where the employees are in an isolated area and only have the choice to work for a single employer. Under monopsony power a small increase in the minimum wage will result in an increase in employment. The increase in wages effectively transforms the behaviour of low-wage firms into that of high-wage firms.

In the case of a pure monopsony, a firm can reduce its wages and only lose part of its workforce. This occurs because some portion of the workers are either unable or unwilling to leave. This is not the case in a perfectly competitive labour market, where all employees would leave to maintain a higher wage. Firms under 
monopsony will reduce wages, because even though they are losing workers, which reduces their output and hence revenue, they have also lowered their wage bill for their remaining workers, and have hence lowered their production costs. A firm will continue to lower wages until the reduction in revenue exceeds the reduction in costs.

If the monopsony model holds, imposing a minimum wage can result in an increase in employment, under certain conditions. If a minimum wage is introduced it means that the firm will now have to pay higher wages for all its employees, increasing the wage bill. This will result in the firm expanding employment in order to increase production and, hence, revenue until the increase in revenue offsets the increase in costs.

The major problem for exponents of the above view in Australia is to explain why employers of the lowest-paid workers would have monopsony power, as there are numerous employers of low-skilled labour, and there are few impediments to these workers moving to another employer, particularly in the long term when employees can change industry and location. In a monopsony labour market you would expect to see few employers and numerous barriers to entry to new firms.

Also, if monopsony power existed, we should observe a fall in output prices as the minimum wage increases. This is because an increase in the wage will increase employment, which would expand production. For the firm to be able to sell this additional output, it would have to decrease output prices to encourage consumers to buy the extra output. All the empirical evidence shows that prices rise when minimum wages rise (ACCI 2006).

Even if there is monopsony power, the minimum wage can only rise within a certain range before it starts having a negative effect on employment, even if it initially had a positive one. Card and Krueger (1998) themselves acknowledge that if the minimum wage is raised too much, job losses will arise. The wage at which employment falls will vary across industries, making minimum wage a fairly useless economy-wide policy.

\section{How can the system be improved?}

Although a cogent argument can be made for having no minimum wage (see, for instance, Moore 2005), realistically this is not a politically acceptable option given the level of support the minimum wage receive from all major political parties. The emphasis in this paper is how the system of setting the minimum wage could be improved. One of the major reasons for the setting up of the AFPC was to increase the clarity and transparency in determining the minimum wage. Unfortunately, this has not occurred and it is hard to argue that the AFPC is an improvement on the process conducted by the AIRC. For instance, a frequent criticism of the AIRC was that it did not adequately explain how it arrived at 
the specific values for wage adjustments and this has hardly improved with the AFPC.

What is urgently needed in a new system establishing itself as a proper means of adjusting the minimum wage is a framework that others can understand, especially those who are compelled to pay the increase. There needs to be established a series of guidelines such that those who are affected by such decisions are able to forecast outcomes which can then be used in their own budgeting. It is important that a level of certainty be established so that business is not continually faced with an unpredictable change in costs based on a decision-making process for which there are no clear principles.

The lack of clarity is unsatisfactory. More to the point, if increases can be predicted by nothing more than examining past movements in the CPI, then certainty of some kind is being given, but will have its own repercussions on the ability of the labour market to provide jobs for all who seek work.

Conforming to the movement in the CPI will also build in a form of expectation among the workforce so that any increase that is not at least as large as the movement in consumer prices will be instantly dismissed as illegitimate. It is creating a rod for its own back for the system, especially in its early stages, to be giving the impression that the aim is to compensate workers for the rise in prices over the period since the last increase. This is a form of economic addiction that will create industrial disruption over the longer term, especially if inflationary pressures increase. Under such a regime, any increase in the price level, irrespective of the cause (petrol prices and the cost of bananas being recent examples) can become part of the adjustment process.

It would be a serious mistake to consider inflation as a phenomenon of the past. Although Australia's recent history with respect to inflation has been good, there is a need not to be complacent (Edey 2007). The apparent strength of the Australian economy is raising fears among some commentators of inflationary pressures and the possibility of higher interest rates even given the raises in 2007 and early 2008.

It is generally recognised that Australia's previous regime of centralised wage bargaining with indexation was a major reason for the perpetuation of inflation in the 1970s and early 1980s (Dwyer and Leong 2002). The success of the Prices and Incomes Accord in reducing inflation was to act as a circuit-breaker in the centralised system, reducing real wages by 10 per cent below what would have been expected under a strict indexation regime (Lewis and Spiers 1990). A major feature of the more decentralised wage-bargaining system, begun under the Hawke/Keating governments and continued under the Coalition, is the decoupling of wages and prices through automatic indexing of wages to inflation, removing a mechanism for the direct transmission of prices to wages and, in turn, wages to prices. For much of the period of centralised wage determination, there was 
some form of regular indexation of wages to the CPI. In wage bargaining today this does not generally occur. It would therefore be inappropriate for indexation to be the major focus of pay rises for the approximately 20 per cent of workers on awards determined by the AFPC.

Removing the automatic link between wages and prices, minimising flow-on effects of awards and lengthening the period between wage adjustments have been important in the management of inflation in Australia (Dwyer and Leong 2001). Regular adjustment of award wages to the CPI should be seen as a backward step in sensible anti-inflation policy.

The AFPC and its successor must provide a framework such that:

- it provides a genuine safety net which does not rigidly keep pace with short-term economic change or which is subject to continuous, unpredictable revision. It should also not proceed from the assumption that strong economic growth automatically provides the rationale for increased minimum wages;

- it must allow those who make submissions to understand what the criteria for making decisions are so that these can be addressed in their own submissions; and

- any minimum wage increase should apply only to the federal minimum wage; increases above this level should be by workplace bargaining.

The framework must make it clear from the start that its role is to provide a safety net that underpins the system in a way that encourages employees to bargain with their own employers. Wage earners should not come to expect that adjustments in the minimum wage will be equivalent in practice to increases that would otherwise have had to be negotiated with an employer.

Employers should also not have the luxury of allowing the decisions of the AFPC to stand as a proxy for ensuring that the wages paid are sufficiently high to retain their own workforce to meet all of the requirements of their businesses. Being paid according to the award should not be seen by employers as setting a standard so high that workers should under normal circumstances be satisfied with their level of compensation. The minimum wage should be seen by all as a safety net paid only to those who are generally low-skilled and whose productivity contribution is equally low. The decisions of the AFPC should not be part of a process that fuels an inflationary process.

\section{An advocate for the jobless?}

One of the major problems with the current system of setting awards is that there is no lobby group for the jobless, with most welfare groups arguing for higher wages. The focus of policy should be to raise the incomes of low-income households rather than of low-wage workers. There is substantial evidence that many low-wage workers are in relatively high-income households and that poor 
households are usually poor because members of the households are out of work (McGuiness et al. 2006; Lloyd et al. 2004; Tsumori 2004). Thus, facilitating jobs growth should take preference over raising wages of those in work.

Unfortunately, the inflexibility resulting from awards is compounded by the social security system. Table 2 presents some interesting comparisons between the maximum disposable income for those whose income is only derived from social-security benefits entitlements and the disposable income for those working full time on the minimum wage and receiving the (reduced) welfare payments they are entitled to. The disposable-income figures take no account of non-cash benefits to which many recipients are entitled. Non-cash benefits include concessions for health and welfare services, housing, transport, education and other goods and services.

Table 2 shows that for single people, in particular, there are significant increases in disposable income by moving from social security to a job at the minimum wage but that this diminishes for those with children. It is not obvious without further analysis whether the increase in disposable income would be sufficient compensation for the move from no work to full-time work. Nevertheless, for many contemplating moving from joblessness there are high effective marginal-tax rates (AMP/NATSEM 2006) which are a major disincentive to work.

Table 2: Disposable income of selected households with income from only social security payments and the minimum wage plus social security payments, December 2006 (\$ per week)

\begin{tabular}{l|c|c|c}
\hline & Social Security & Minimum Wage & Ratio \\
\hline Single Adult & (a) & plus welfare (b) & (a)/(b) \\
\hline with 1 child & 262.05 & 450.34 & 0.58 \\
\hline pensioner & 429.23 & 649.61 & 0.66 \\
\hline & 307.65 & $\mathrm{~N} / \mathrm{A}$ & \\
\hline Couple (single earner) & & & 0.68 \\
\hline with 2 children & 418.00 & 600.69 & 0.71 \\
\hline pensioner & 587.84 & 829.42 & \\
\hline & 464.70 & $\mathrm{~N} / \mathrm{A}$ & \\
\hline Minimum Wage & & & \\
\hline
\end{tabular}

Source: Poverty Lines: Australia, Melbourne Institute of Applied Economics and Social Research, http://melbourneinstitute.com/ and Australian Fair Pay Commission, Wage Setting Decisions 2/2007, 3/2007, 4/2007 and Reasons for Decisions, p.69, http://www.fairpay.gov.au/fairpay/MinWageDecisionJul2007/.

When income tax on wages and the other benefits and discounts available are included, together with the loss of leisure time and disutility of working in low-skilled jobs, the incentives to work may be low or negative for many. Clearly, changes to the demand side of the labour market, such as greater wage flexibility, must be accompanied by supply-side policies such as major reform of the social security and tax systems. The Coalition government did introduce stricter 
conditions for eligibility for welfare benefits but it is too early to tell what the full impact of these measures will be.

According to Lewis (2002) most unemployment is due to lack of 'effective supply'. These are jobless people for whom, given the current wage and institutional structures, there are no jobs for which they are willing to work or profitable activities which employers can find for them to do. What is required is a raft of policies which increase effective supply. These policies would involve long-run commitment to raising education participation and achievement among the most disadvantaged Australians. This is no small task, which involves improving the efficiency of the education system and widespread reform of social security, taxation and income-support systems for low-income households (Lewis 2002).

However, supply-side policies can only work if there are flexible wages. Supply-side policies shift the effective supply. People who were previously unemployable or unwilling to work now enter employment as the real wage falls for people at the margin. However, new jobs can only be created if there is an increase in demand for low-skilled labour which requires downward flexibility in wages. People willing to supply their labour can only make this effective if employers can find profitable work for them to do.

\section{Conclusion}

It has been argued here that reducing joblessness among Australia's most disadvantaged is not easy and requires a whole range of labour-market, welfare, social and education policies. However, part of any package of measures would be incompatible with the current minimum wage.

The AFPC has replaced the previous means of setting the minimum wage and other award conditions. Importantly, the AFPC is required to take account of the impacts of wage rises on employment and unemployment. The inclusion of the interests of the most disadvantaged, the jobless, rather than simply the interests of the unions and employer groups, has the potential to be a major step forward. Setting a wage that allows everyone who wishes to work to find paid employment must be the core aim of the process. Pricing workers out of jobs should be strenuously avoided.

Market forces, as exemplified by supply-and-demand analysis, should underpin the logic of the decisions. There are many considerations that go into the final determination of the adjustment but primary among these must be the certainty that excessive wage increases will keep many people out of work who otherwise would find jobs

Although some employer groups argued that the old system should be abolished they have found that they have another one very much like it in its place, a major difference being that there is only the opportunity for submission 
of argument and no opportunity for debate on the relative merits of these submissions.

The suggestion that the minimum wage must be raised to a level that allows wages to compete with the welfare payments that might instead be received is economically unsound and deeply insulting to the unemployed. The decision to work rather than live on welfare is thus taken from the unemployed who would to some extent be in a position to choose whether to work or remain on welfare. Welfare should be seen as an entitlement for those who have no alternative. It was incumbent on the AFPC to point out the problems inherent with setting a minimum wage which maximises employment in the context of a generous social-security system.

There are a number of technical issues in regard to the conduct of the AFPC wage decisions that are important considerations.

There is, primarily, a question of whether the AFPC has stayed within its Terms of Reference. The objective of wage determinations of the AFPC and matters to which it is to have regard is set out in section 23 of the Workplace Relations Act:

...the objective of the AFPC in performing its wage-setting function is to promote the economic prosperity of the people of Australia, having regard to the following:

The capacity for the unemployed and low paid to obtain and remain in employment;

Employment and competitiveness across the economy;

Providing a safety net for the low paid;

Providing minimum wages for junior employees, employees to whom training arrangements apply, and employees with disabilities that ensure that these employees are competitive in the labour market.

Section 24 of the Workplace Relations Act gives the AFPC wide powers to determine its own procedures. The AFPC may determine the timing and frequency of wage reviews; the scope of particular wage reviews; the manner in which wage reviews are to be conducted; and when wage-setting decisions are to come into effect.

The brief the AFPC has made up for itself is a very wide one which seems to go beyond the intent of the Act. The terms of reference of any body which replaces the AFPC should be looked at thoroughly to ensure that they are not being exceeded. It is not clear at the time of writing exactly what will be the approach taken and the terms of reference of the Rudd government's alternative to the AFPC under the umbrella of the omnibus industrial-relations body Fair Work Australia. 
A major fault in the AFPC process is that it is one in which submissions can only be addressed to the issues and not to the submissions of other parties. The AFPC and its successor should welcome the observations of individual parties on the submissions made by others. It will deepen the process.

The relevant decision-making body within Fair Work Australia set the task of determining the minimum wage needs to be more clear cut about its own reasons for a decision. Statements by the Chair of the AFPC outside the process that he was pleased to be able to be told of the financial difficulties faced by those on low incomes suggests that the process is attempting the impossible. Adjusting the minimum wage should not be seen as an aspect of social welfare.

The process should adjust the minimum wage only. Adjustment of all award rates perpetuates the centralised system. Minimum-wage adjustment allows the labour market to adjust, while the maintenance of the award structure prevents relative wage movements in response to changes in the market from taking place.

Hopefully the new Fair Work Australia will take on board the criticisms of the AFPC and introduce a more satisfactory process

\section{References}

AMP/NATSEM 2006, Trends in Effective Marginal Tax Rates 1996-97 to 2006-2007, AMP.NATSEM Income and Wealth Report, Issue 14, September.

Australian Bureau of Statistics (ABS) 2006, Underemployed Workers, Cat. No. 6265.0, ABS

Australian Chamber of Commerce and Industry (ACCI) 2006, Submission to the Australian Fair Pay Commission, Chapter 8.2.4.

AIRC, Australian Industrial Relation Commission 2005, Safety Net Wage Decision, June.

Argy, F. 2005, 'An Analysis of Joblessness in Australia', Economic Papers 24(1): 61-74.

Bernie, K. and Downes, P. 1999, 'The Macroeconomics of Unemployment in the Treasury Macroeconomic (TRYM) Model', TRYM Related Paper No.20, paper presented in the RBA seminar series, 27 January, Reserve Bank of Australia, Sydney.

Brown, C., Gilroy, C. and Kohen, H. 1982, 'The Effect of the Minimum Wage on Employment and Unemployment', Journal of Economic Literature 20: 487-528.

Card, D. and Krueger, A. B. 1995, Myth and Measurement: The New Economics of the Minimum Wage, Princeton University Press, New Jersey. 
Card, D. and Krueger, A. B. 1998, 'Unemployment Chimera', Washington Post, 6 March.

Daly, A., Nguyen-Hong, D., Eldridge, D., Gabbitas, O., McCalman, P. 1998, Youth Wages and Employment, Productivity Commission Staff Research Paper, Ausinfo, Canberra, October.

Dyer, J. and Leong, K., Changes I the Determinants of Inflation, Reserve Bank of Australia, Research Discussion paper, 2002-02.

Edey, M. 2007, 'Australia in the Global Economy', Address to the Australia \& Japan Economic Outlook Conference 2007, Sydney, 16 March.

Ehrenberg, R. G. 1995, 'Review Symposium on Myth and Measurement: The New Economics of the Minimum Wage', Industrial and Labour Relations Review 48(4): 827-28.

Hamermesh, D. S. 1993, Labour Demand, Princeton University Press, New Jersey.

Kelly and Lewis 2006, 'Measurement of Skill and Skill Change' in Brown, P, Liu, S. and Sharma, D., Contributions to Probability and Statistics: Applications and Challenges, World Scientific, Singapore.

Leigh, A. 2003, 'Employment Effects of Minimum Wages: Evidence from a QuasiExperiment', Australian Economic Review 36(4): 361-73.

Leigh, A. 2004, 'Minimum Wages and Employment: Erratum' Australian Economic Review 37(1): 102-5.

Lewis, P. E. T. 1985, 'Substitution Between Young and Adult Workers', Australian Economic Papers 24(44): 115-26.

Lewis, P. E. T. 1997, 'The Economics of the Minimum Wage', Australian Economic Review 30(2): 204-7.

Lewis, P. E. T. (2002), 'What Do We Know About Job Creation?', Australian Journal of Labour Economics 5(2): 279-88.

Lewis, P. E. T. 2004, 'The Australian Labour Market and Unemployment in 2004', paper presented to the H. R. Nicholls Society, Melbourne.

Lewis, P. 2005, 'Low Pay or No Pay?', Policy 21(3): 14-20.

Lewis, P. E. T. 2006, Minimum Wages and Employment, report commissioned by the Australian Fair Pay Commission, http://www.fairpay.gov.au/NR/rdonlyres/24E4540F-4CC4-44F4-9361-2396D6AC2883/0/Minimumwagesandemployment_CLMR.pdf.

Lewis, P. E. T. and McDonald, G. 2002, 'The Elasticity of Demand for Labour in Australia', Economic Record 78(240): 18-30.

Lewis, P. E. T. and Spiers, D. J. 1990, 'Six Years of the Accord - an Assessment', Journal of Industrial Relations 32(1): 53-68. 
Lewis P. E. T. and Seltzer, A. 1996, 'Labour Demand' in Norris, W. K. and Wooden, M., The Changing Australian Labour Market, AGPS, Canberra.

Lloyd, R., Harding, A. and Payne, A. 2004, 'Australians in Poverty in the $21^{\text {st }}$ Century', paper presented at the Conference of Economists, University of Sydney, 27-30 September.

McGuinness, S., Freebairn, J. and Mavromaras, K. 2006, 'Characteristics of Minimum Wage Employees', paper prepared for the Australian Fair Pay Commission.

Moore, D. 2002, 'Minimum Wages: Employment and Welfare Effects or Why Card and Krueger Are Wrong', Australian Bulletin of Labour 28(3): 163-83.

Neumark, D., Schweitzer, M. and Wascher, W. 2000, 'The Effects of Minimum Wages Throughout the Income Distribution', National Bureau of Economic Research Working Paper 7519, Cambridge, Massachusetts.

Osterman, P. 1995, 'Review Symposium on Myth and Measurement: The New Economics of the Minimum Wage', Industrial and Labour Relations Review 48(4): 827-8.

Robson, A. 2004, 'A Labour Market Fable', Policy 20(4): 25-30.

Seltzer, A. 1997, 'An Evaluation of the International Evidence on the Employment Effects of Minimum Wage Legislation' Australian Economic Review 30(2): 208-14.

Tsumori, K. 2004, The Road to Work - Freeing Up the Labour Market, Centre for Independent Studies, Policy Monograph 64. 